\title{
Antifungal effect of aqueous and ethanolic extracts of neem leaves, stem bark and seeds on fungal rot diseases of yam and cocoyam
}

\author{
Chukwuma S. Ezeonu ${ }^{\text {* }}$, Chinedu Imo ${ }^{1}$, Dawn I. Agwaranze ${ }^{2}$, Assumpta Iruka ${ }^{1}$ and Abraham Joseph ${ }^{1}$
}

\begin{abstract}
Background: Fungal rot diseases of white yam (Discorea rotundata) tubers and cocoyam (Colocasia esculenta) are the major post-harvest challenges in the availability of these root tubers. The use of biological extract of plants will prevent post-harvest losses without any negative health challenge.
\end{abstract}

Methods: Microwave-assisted method of extraction was used for both aqueous and ethanolic extracts of neem samples. Fungal-rotted yam and fungal-rotted cocoyam samples were collected, and fungi from them were cultured on potato dextrose agar (PDA). The same medium was used for subculturing until pure fungal isolates were obtained. Pathogenicity tests were carried out on the yam and cocoyam tubers by inoculating with isolated fungi. The neem extracts were integrated into the PDA and their antifungal effects examined.

Results and discussion: From the yam, Aspergillus ochareus, Sclerotium rolfsii and Lasidiodiplodia theobromae were isolated, while Aspergillus niger, Aspergillus oryzae and Rhizopus stolonifer were isolated from cocoyam samples. After 14 days of inoculation, isolated fungi were shown to be highly pathogenic except $R$. stolonifer and $A$. ochareus, which showed moderate pathogenicity. All the plant extracts showed antifungal activities at varied percentage mean zones of inhibition. The inhibition against fungal growth from the isolates of the rotted cocoyam gave mean inhibition between $39.53 \pm 8.39 \%$ and $96.76 \pm 1.60 \%$. Except for ethanolic stem bark extract which gave $39.53 \pm 8.39 \%$ limited zone of inhibition against $A$. niger growth, the rest of the extract exhibited good zones of inhibition against cocoyamisolated fungi ranging between $72.87 \pm 3.55$ and $96.79 \pm 1.60 \%$. On fungal isolates from yam, the mean percentage zones of inhibition of all extracts of the neem plant parts showed more effectiveness than the positive control (Ketoconazole) against L. theobromae growth. Aqueous stem bark extract with $93.80 \pm 1.78 \%$ zone of inhibition showed comparable effectiveness to the control (100\% inhibition) against A. ochareus growth, while against S. rolfii growth, there was good inhibition by all the extracts though not to the extent as that of the control.

Conclusion: The fungitoxic potential of these plant extracts on rot-inducing fungi of stored yam and cocoyam suggests that the above extracts used in this study can be put to use by farmers as alternative to commercial/synthetic fungicides.

Keywords: Antifungal, Fungi, Inhibition, Neem, Pathogenicity

\footnotetext{
*Correspondence: chuksmaristos@yahoo.com

1 Department of Biochemistry, Federal University Wukari, Wukari, Taraba

State, Nigeria

Full list of author information is available at the end of the article
} 


\section{Background}

Neem plant (Azadirachta indica) is well known for its medicinal properties. Known with different names in different parts of the world (Indian Lilac, Margosa, Dogonyaro), neem has been well established for its medicinal properties such as in treatment of various ailments. In Africa, it is popular in the treatment of malaria and for its effectiveness as an antibacterial agent. Recently, $A$. indica like other similar botanicals is gaining prominence in its application in treatment of plant-related diseases. In a research conducted by Mahmoud et al. [1], 5\% aqueous leaf extract of neem was shown to cause inhibition in growth of six tested fungal pathogens (Aspergillus flavus, Aspergillus fumigatus, Aspergillus niger, Aspergillus terreus, Candida albicans and Microsporum gypseum). In another research, aqueous neem extracts inhibited $A$. niger more than $C$. albicans, while alcohol neem extract inhibited C. albicans better than A. niger [2]. Neem plant is effective against fungal growth, a quality which may be used in increasing the shelf life of plant tubers after harvest.

Yam (Discorea spp) belonging to the genus "Dioscorea" is a monocotyledon which is annually produced worldwide. According to IITA [3, 4], Nigeria accounting for $71.9 \%$ of yam production worldwide remains the principal producer. Yam-production zones show dominant stretches from Cote d'ivoire through Ghana, Togo, Benin, Nigeria, Cameroon, Gabon, Central African Republic and the Western part of the democratic Republic of Congo, while in East Africa, Sudan and Ethiopia are the major yam producers [5]. According to Opara [6], soft rots in yam are caused mainly by fungi especially Penicillium spp, Fusarium oxysporum and Botrydiplodia theobromae, while dry rots among others is principally caused by Rosselinia and Sphaerostilbe. Other fungi also include Rhizopus nodosus and Fusarium solani. Infection in the field can persist and lead to rotting during storage, and control strategy involves treating tubers with systemic fungicide or alkaline material such as Bordeaux mixture and providing adequate aeration and inspecting stored tuber regularly [6]. However, the ideal treatment would be the use of organic fungicide such as neem plant (leave, root and stem bark) extracts; since neem itself is commonly consumed as herb and useful as traditional medicine. Therefore, it should be less toxic and biologically healthy in food preservation. Cocoyam belongs to the Araceae family [7]. Colocasisa esculenta, otherwise known as taro, is more popular in Nigeria than Xanthosoma sagittaifolium variety, also known as tannia [8]. Some of the popular uses of cocoyam in Nigeria include use as soup thickener, consumption as porridge with beans, cassava chips and vegetables as well as formation into chips. It is used as antipoisoning and wound-healing agents by applying the fresh mash in the opening of sores. Thus, it possesses antibiotic properties. It is also formed into flour. This important tuber is consumed both by human and domestic animals. Boiling and fermenting before consumption help to reduce the oxalic acid content in it, which causes itching in some local varieties. Cocoyam is a perennial crop grown mainly for its edible roots [7]. NRCRI [9] report stated that after cassava and yam, cocoyam is the third most important crop among the root and tuber crop cultivated and consumed in Nigeria, and it is nutritionally superior to cassava and yam. Cocoyam is grown for its edible starchy corm and leaves, and is a major source of cheap vegetable carbohydrates, protein, fats, crude fibre, ash, carotene, thiamine, riboflavin, niacin, vitamin $\mathrm{C}$ and are more digestible compared to other root crops [10]. Cocoyam is a tuber crop consumed in all states in the south-east [11] and most parts of north-central Nigeria, being a popular root tuber. FAOSTAT [12] stated that in 2008, Nigeria was estimated to produce 5.39 million metric tonnes out of a total of 11.77 million metric tonnes of cocoyam world production. The major setback in cocoyam production according to Igbozulike [7] is deterioration of the corms, and the factors responsible for the loss in quality have been identified to include physiological, mechanical, rodents, birds, insect infestation as well as pathogenic, but most importantly fungal rot.

\section{Methods \\ Plant collection}

Seeds of neem were collected from tree plantation at Mission quarters, Wukari, Taraba State, Nigeria. The mature healthy seeds, leaves and stem bark were also collected randomly from different neem trees. The leaves, stem bark and seeds were dried after being washed under running tap water to eliminate dust and other foreign particles.

\section{Sterilization of materials}

All glass wares used in this study were washed with detergent, rinsed and sterilized in a dry, ventilated oven at $160{ }^{\circ} \mathrm{C}$ for $2 \mathrm{~h}$. All media were sterilized by autoclaving at a temperature of $121^{\circ} \mathrm{C}$ and 15 psi for $20 \mathrm{~min}$. The scalpel, cork borer and inoculating needle were sterilized by dipping them into $70 \%$ ethanol and passing them over a Bunsen burner flame until red hot.

\section{Ethanolic and aqueous extraction (microwave-assisted extraction-MAE)}

The neem leaves, stem bark and seeds were grounded manually to form the smallest possible size after drying and sieved. The sample $(20 \mathrm{~g})$ was measured and added into the extraction container. Ethanol or distilled water 
(separately for ethanol and aqueous extraction) (200 ml) was then added, tightly covered and placed in the microwave oven. The oven door was closed and the power set between 400 and 680 Watts and allowed to run for a short burst of $3 \mathrm{~min}$ and stopped. The set-up was carefully removed and allowed to cool before re-introducing it for another burst of $3 \mathrm{~min}$. This process was repeated until achieving a cumulative extraction period of $45 \mathrm{~min}$. The set-up was allowed to cool before it was opened and filtered. The filtrate was then concentrated and used for antifungal assays.

\section{Preparation of culture medium}

Throughout the study, the assayed culture medium employed was LAB M Potato Dextrose Agar (PDA). This medium was used for the growth and maintenance of the fungal isolates. The preparation of Potato Dextrose Agar (PDA) was done according to the manufacturer recipe ( $39 \mathrm{~g}$ in $1 \mathrm{l}$ of water). The medium was sterilized by autoclaving at $121{ }^{\circ} \mathrm{C}$ and $15 \mathrm{psi}$ for $20 \mathrm{~min}$ for complete dissolution and homogeneity. Thereafter, it was allowed to cool to temperature of between 42 and $45{ }^{\circ} \mathrm{C}$. One capsule of chloramphenicol was added to every $500 \mathrm{ml}$ of sterile cooled PDA so as to prevent bacteria growth [13]. Approximately $15 \mathrm{ml}$ of the cooled amended PDA was poured into each sterile petri dish of $8.6 \mathrm{~cm}(86 \mathrm{~mm})$ diameter to solidify. The petri dishes that contained the medium were incubated for $24 \mathrm{~h}$ at ambient temperature $\left(28^{\circ} \mathrm{C}\right)$ to check for sterility before use as described by Cheesebrough [14].

\section{Isolation of fungi}

The isolation technique used by Onyike and Maduewesi [15] was employed in this study. A small section of the yam or cocoyam tissue showing advancing margin of rot and adjoining healthy tissue were cut using sterilized scalpel and cork borer whose surface was sterilized with $70 \%$ ethanol. The peeled portions of the yam or cocoyam obtained with the cork borer were placed on the solidified agar. Three peeled portions were placed per plate with equal distance between them. Three replicate plates for each of the rotten portion of site were made for each yam or cocoyam variety. The plates were incubated at $27 \pm 2{ }^{\circ} \mathrm{C}$ for 7 days. Fungi associated with the yam or cocoyam rot affected tissues were observed and the frequency of isolation determined using method of Okigbo and Ikediugwu [16]. Subculturing was done to obtain pure cultures of the isolates.

\section{Identification of fungal isolates}

Subculturing of the isolates was made to obtain pure culture. The colonies growing on the plates were identified macroscopically and microscopically. Some examples are shown in Fig. 1a-f below. Colony colour, type (compact, loose, aerial hyphae), texture (velvety, cottony, coarse) shape and growth pattern were observed. Direct observation of culture under the light microscope (low power) by careful preparation of slides, staining with cotton blue-in-lactophenol was done. Detailed drawings of the diagnostic features and identification manual and guides according to Alexopoulos [17]; Nelson et al. [18]; Rippon [19]; Samson et al. [20]; and Snowdon [21] were used.

\section{Pathogenicity test}

The pathogenicity test was carried out to establish which of the fungal isolates caused the rot and to determine whether they could induce similar symptoms on inoculation and be re-isolated, thus fulfilling Koch's postulates. The method of Okafor [22], Okigbo and Ikediugwu [16] were adopted for the pathogenicity study. The pure fungal isolates obtained from infected yam tubers of Discorea rotundata and Cocoyam corm of Colocasia esculenta variety, respectively, for the period of the collection were used for inoculation. Healthy yam tubers (D. rotundata variety) and Cocoyam corm (C. esculenta variety) were surface-sterilized with $70 \%$ ethanol. Each healthy tuber was bored into about $1 \mathrm{~cm}$ deep, with a sterile $6 \mathrm{~mm}$ diameter cork borer at three different points on the yam and cocoyam surface (proximal, middle and distal regions). Another $6 \mathrm{~mm}$ sterile cork borer was used to cut about $5 \mathrm{~mm}$ of mycelia disc from edge of a 5 days old culture of each fungus isolate. The mycelia discs were used to inoculate the holes created by scooping out the plant tissue. The scooped out tissue of the yam and cocoyam were replaced after $5 \mathrm{~mm}$ pieces had been cut off to compensate for the thickness of the fungal culture. Two whole tubers of yam and two whole corm of cocoyam were inoculated per fungus. The control setup consists of tubers that were similarly bored into and inoculated with sterilized PDA agar discs.

The wounds were sealed with petroleum jelly and inoculated tubers were placed in transparent polythene bags whose inside has been moistened with cotton wool soaked in sterile distilled water to maintain a high humidity. The inoculated tubers and corms were kept in the laboratory at room temperature for about 14 days and assessed for rot development by cutting through the points of inoculation where rots developed. The pathogens were re-isolated as previously described and their cultural and morphological characteristics were compared with those of the original isolates. 


\section{Antifungal activity of the extracts}

Effect of plant extract on mycelia growth of the test fungi was studied using the food poisoning techniques [23]. One millilitre $(1 \mathrm{ml})$ of each plant extract was dispensed per petri dish and $9 \mathrm{ml}$ of the media (molten PDA) was added to each of the petri dish containing extract and carefully spread evenly over the plate, this gave rise to PDA-extract mixture with $10 \%$ extract concentration. This was used for examining the inhibition of mycelia growth. The plates were gently rotated to ensure even dispersion of the extracts. The agar extract mixture was allowed to solidify and then inoculated at
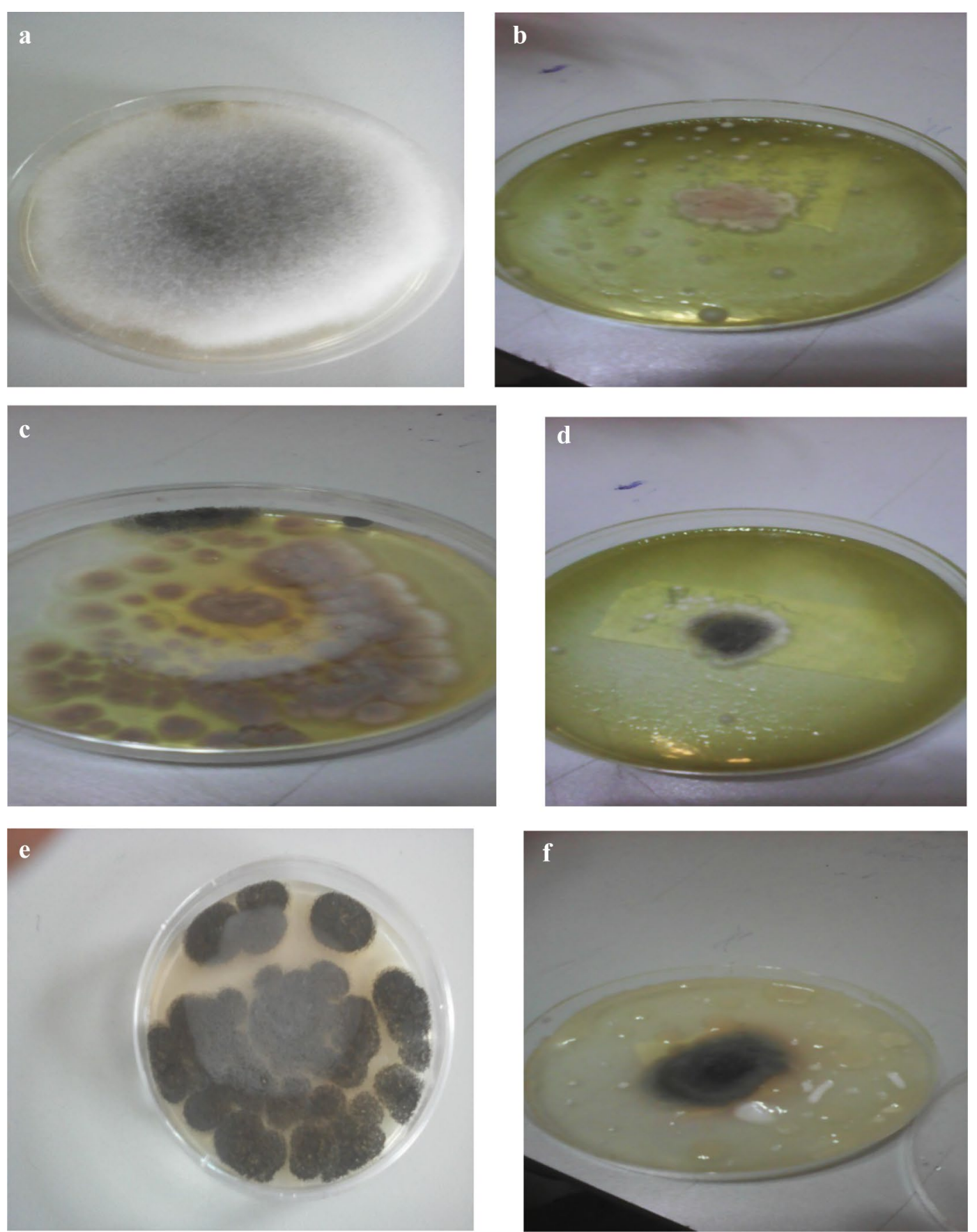

Fig. 1 Images of the pure isolates and inhibited isolates from cocoyam. a Rhizopus stolonifera. b Plate with inhibitions against Rhizopus stolonifera. c Aspergillus oryzae. $\mathbf{d}$ Plates with inhibitions against Aspergillus oryzae. e Aspergillus niger. f Plate with inhibitions against Aspergillus niger 
the centre with a $4 \mathrm{~mm}$ diameter mycelia dish obtained from the colony edge of 7-day old pure cultures of each of the test fungi. Each treatment consists of three replicates. The negative control set-up consist of blank agar plate (no extract) inoculated with the test fungi as described above. Petri-dishes dispensed with molten PDA and one $\mathrm{ml}$ of ketoconazole dissolved in distilled water inoculated with each test fungus served as the commercial fungicides. All the plates were incubated at $28{ }^{\circ} \mathrm{C}$ for 5 days and examined daily for growth and presence of inhibition. Colony diameter was taken as the mean growth along two directions on two predrawn perpendicular lines on the reverse side of the plates. The effectiveness of the extract was recorded in terms of percentage inhibition, which was calculated according to the method described by Whipps [24].

$$
\text { Percentage inhibition }=R 1-R 2 \times \frac{100}{R 1},
$$

where $R 1$ is the farthest radial distance of pathogen in control plate, while $R 2$ is the farthest radial distance of pathogen in extract-incorporated agar plates.

\section{Results and discussion}

\section{Pathogenicity test}

From the yam, A. ochareus, S. rolfsii and L. theobromae were isolated, while $A$. niger, $A$. oryzae and $R$. stolonifer were isolated from cocoyam samples (Tables 1 and 2). Pathogenicity tests in cocoyam revealed that $A$. niger, $A$. oryzae and $R$. stolonifer caused rot. The nature of rot varies between the inoculated cocoyam tubers with various selected fungi. A. niger shows dry and soft rotting, and $A$. oryzae caused dry rot (Table 3 ). Among isolated fungi (Fig. 2), A. niger and A. oryzae are the most pathogenic, while $R$. oryzae is the least pathogenic as evident from the weight loss. There was obvious reduction in weight observed in corms of cocoyam exposed to fungal pathogenicity. Order of weight reduction from high to low in the cocoyam exposed to the fungi was $23.43 \mathrm{~g}$ (A. niger), $16.29 \mathrm{~g}$ ( $R$. stolonifer) and $14.84 \mathrm{~g}$ (A. oryzae). The reduction in weight of the control (uninfected cocoyam) was only $1.73 \mathrm{~g}$. Considering the moderate sizes of the cocoyam in Fig. 1, there was indeed high loss in weight and thus great pathogenicity of fungi examined.

Pathogenicity tests in yam tubers (Table 4) revealed rots in them as a result of infestation with L. theobromae, $A$. ochareus and $S$. rolfsii. The nature of rot varies between the inoculated yam tubers with various selected fungi. $L$. theobromae shows wet rotting, S. rolfsii caused rot with dirty white colour. Among isolated fungi, A. ochareus is the least pathogenic as evident from the weight loss (Fig. 3). Weight loss recorded due to fungal pathogenicity test in yam is shown in the order of weight loss per fungi from the most to the least as $326.25 \mathrm{~g}$ (S. rolfsii), $199.47 \mathrm{~g}$ (L. theobromae) and $164.54 \mathrm{~g}$ (A. ochareus). The control which was not infected showed only $6 \mathrm{~g}$ decrease in weight after 14 days. These results established the fact that these fungi has high pathogenicity as depicted by the drastic reduction in weight as well as the tissue rot sighted thereafter.

These results demonstrated the fact that all the fungi investigated for pathogenicity of both yam and cocoyam are indeed pathogenic.

\section{Antifungal activity of the extracts on fungi isolated from cocoyam}

Analysis of variance at $95 \%$ showed that all the parts (leaf, bark and seed) of the test plant (neem) used in this study significantly $(P<0.05)$ inhibited the growth of the fungal organisms against cocoyam rot (Table 5). Ethanolic seed extract (ESE) had the highest inhibitory effect against $A$. oryzae (91.47 $\pm 2.93 \%$ inhibition), while it was also effective against $R$. stolonifer ( $88.37 \pm 1.17 \%$ inhibition), and $A$. niger (84.88 $\pm 3.07 \%$ inhibition). The antifungal effects of aqueous seed extract (ASE) on those fungi showed inhibitions of $85.66 \pm 2.92 \%$ (A. oryzae), $81.78 \pm 2.92 \%$ ( $A$. niger) and $79.07 \pm 2.33 \%$ ( $R$. stolonifer), which though without any significant difference, $(P>0.05)$ compared to that of ethanolic seed extract (figures are shown above), showed lower inhibition. Thus, both ESE and ASE showed similar antifungal activities.

Ethanolic leave extract (ELE) showed great growth inhibitory effect of $90.70 \pm 2.33 \%$ against A. oryzae, which was significantly higher $(\mathrm{P}<0.05)$ than the growth

Table 1 Macro- and micro-features of fungi isolates from Yam (Discorea rotundata)

\begin{tabular}{|c|c|c|c|}
\hline S/no & Isolates & Colony characteristics & Microscopy \\
\hline 1. & Aspergillus ochareus & $\begin{array}{l}\text { Growth on PDA was rapid and fast. Powdery } \\
\text { yellow colour almost covering the plates after } \\
72 \mathrm{~h}\end{array}$ & $\begin{array}{l}\text { Non-septate conidiophores arising from thick-walled foot cells. } \\
\text { Each conidiophore ends in a terminal-enlarged spherical swell- } \\
\text { ings. Conidia borne by phialides arising from a terminal swelling } \\
\text { on the conidiophores }\end{array}$ \\
\hline 2. & Lasiodiplodia theobromae & Dirty white with black underneath & Mycelium are septate; chlamydospores are intercalary and terminal \\
\hline 3. & Sclerotium rolfsii & Colony is brown to black, globose and compact & Mycelium lack conidia. Mycelium usually light and straight \\
\hline
\end{tabular}


Table 2 Macro- and micro-features of fungi isolates from cocoyam corm (Colocasia esculenta)

\begin{tabular}{|c|c|c|c|}
\hline S/no & Isolates & Colony characteristics & Microscopy \\
\hline 1. & Aspergillus niger & $\begin{array}{l}\text { Growth on PDA is rapid and fast. Powdery black colour } \\
\text { almost covering the plates after } 72 \mathrm{~h}\end{array}$ & $\begin{array}{l}\text { Non-septate conidiophores arising from thick-walled foot } \\
\text { cells. Each conidiophores ends in a terminal enlarged } \\
\text { spherical swellings. Conidia borne by phialides arising } \\
\text { from a terminal swelling on the conidiophores }\end{array}$ \\
\hline 2. & Aspergillus oryzae & $\begin{array}{l}\text { Growth on PDA is rapid and fast. Powdery brown colour } \\
\text { almost covering the plates after } 72 \mathrm{~h}\end{array}$ & $\begin{array}{l}\text { Non-septate conidiophores arising from thick-walled foot } \\
\text { cells. Each conidiophores ends in a terminal enlarged } \\
\text { spherical swellings. Conidia borne by phialides arising } \\
\text { from a terminal swelling on the conidiophores }\end{array}$ \\
\hline 3. & Rhizopus stolonifera & $\begin{array}{l}\text { Rapid and fast growth of about } 36 \mathrm{~mm} \text { after } 24 \mathrm{~h} \text { which } \\
\text { soon spread and cover the plates. Growth appear as black } \\
\text { pin-head, similar to cotton wool (white in colour) }\end{array}$ & $\begin{array}{l}\text { Mycelium of non-septate hyphae of large diameter. } \\
\text { The sporangiophore bears a terminal black spherical } \\
\text { sporangium. The sporangiophores are erect and may be } \\
\text { branched or unbranched each bearing a single globose } \\
\text { sporangium }\end{array}$ \\
\hline
\end{tabular}

Table 3 Pathogenicity test result (cocoyam)

\begin{tabular}{llll}
\hline S/no & Isolate & $\begin{array}{l}\text { Symptoms } \\
\text { of infection } \\
\text { after } \mathbf{1 4} \text { days }\end{array}$ & Pathogenicity \\
\hline 1. & Aspergillus niger & Dry rot, soft rot & +++ \\
2. & Aspergillus oryzae & Dry rot & +++ \\
3. & Rhizopus stolonifera & soft rot & ++ \\
\hline$+++=$ highly pathogenic & & \\
$++=$ moderately pathogenic & &
\end{tabular}

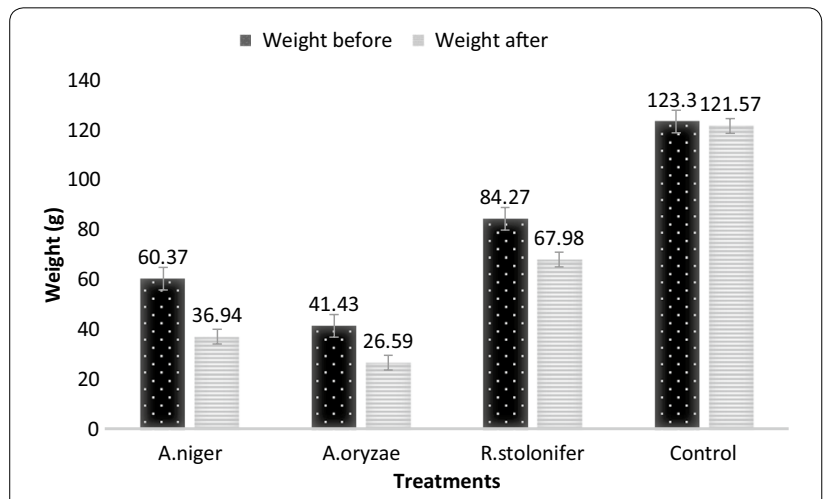

Fig. 2 The mean weight loss of cocoyam after pathogenicity test

inhibition on $R$. stolonifer $(76.74 \pm 2.33 \%)$ and A. niger $(77.52 \pm 1.35 \%)$, even though the extract showed significantly high growth inhibition against the three fungi examined. Aqueous leave extract (ALE) showed inhibitory effects of $85.66 \pm 2.92 \%$ against $A$. oryzae, $75.97 \pm 3.55 \%$ against $R$. stolonifer and $72.87 \pm 3.55 \%$ against $A$. niger. There was no significant difference among growth inhibitions $(P>0.05)$ of the aqueous leave extract (ALE) against the fungal rot in cocoyam in this research, even though it had significant antifungal effect on all the fungi.
Table 4 Pathogenicity test result (yam)

\begin{tabular}{llll}
\hline S/no & Isolate & $\begin{array}{l}\text { Symptoms } \\
\text { of infection } \\
\text { after 14 days }\end{array}$ & Pathogenicity \\
\hline 1. & Aspergillus ochareus & Dry rot & ++ \\
2. & Sclerotium rolfsii & Dry rot & +++ \\
3. & Lasiodiplodia theobromae & Wet rot & +++ \\
\hline$+++=$ highly pathogenic & & \\
$++=$ moderately pathogenic & &
\end{tabular}

Ethanolic stem bark extract (EBE) also showed very high growth inhibition against $R$. stolonifer, $(91.47 \pm 5.85 \%)$ and $A$. oryzae $(84.51 \pm 1.76 \%)$ which were significantly $(P<0.05)$ different from that of $A$. niger $(39.53 \pm 8.39 \%)$. It can be inferred that ethanolic stem bark extract (EBE) was not very effective against $A$. niger as shown by the result above.

Aqueous stem bark extract (ABE) showed significant $(P<0.05)$ high growth inhibition against $A$. oryzae $(96.79 \pm 1.60 \%)$, R. stolonifer $(94.96 \pm 1.34 \%)$ and $A$. niger $(87.21 \pm 1.16 \%)$.

Meanwhile, ketoconazole which was used as the positive control showed $100 \%$ inhibition against the growth of the fungi $A$. oryzae and $89.92 \%$ on $A$. niger, but aqueous stem bark extract (ABE) gave inhibitory effect of $94.96 \pm 1.34 \%$ on the growth of $R$. stolonifer.

Most effective against the growth of $A$. niger is ethanolic seed extract (ESE) $(88.37 \pm 1.17 \%$ inhibition) which does not differ significantly with the control (Ketoconazole) $(89.92 \pm 1.35 \%$ inhibition). Against the growths of $A$. oryzae and $R$. stolonifer, aqueous stem bark extract (ABE) with growth inhibitions of $96.79 \pm 1.60 \%$ and $94.96 \pm 1.34 \%$,respectively, was most effective. In general, it is reasonable to conclude that all the various typed of extracts of neem plant were effective against the 


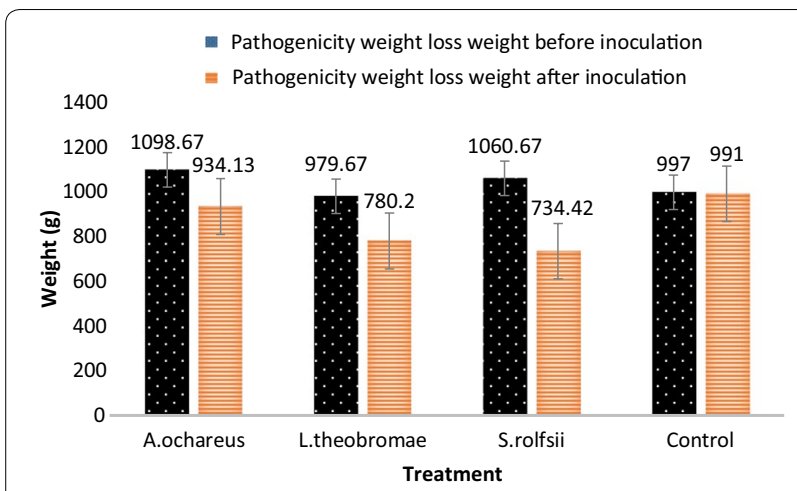

Fig. 3 The mean weight loss of yam after pathogenicity test

growth of the fungai-induced rot in cocoyam examined (except EBE which was not effective against $A$. niger).

\section{Antifungal activity of the extracts on fungi isolated from yam}

The effect of extracts on the test organisms of yam rot was significant $(P<0.05)$. Aqueous extracts of the stem bark $(\mathrm{ABE})$ gave the highest inhibitory effect of $93.80 \pm 1.78 \%$ against $A$. ochareus followed by ethanolic extract of leaf (ELE) with $88.37 \pm 2.33 \%$ inhibition, while ethanolic seed extract (ESE), aqueous seed extract (ASE), aqueous leaf extract (ALE) and ethanolic stem bark extract (EBE) showed inhibition rates of $87.21 \pm 1.16 \%, 82.27 \pm 0.50 \%$, $81.78 \pm 3.74 \%$ and $87.60 \pm 1.34 \%$, respectively (Table 6). The inhibitory effect of ABE was significantly $(P<0.05)$ higher than that of other extracts, while there was no significant difference in the inhibitory effects of ESE, ELE and EBE on A. ochareus. ALE and ASE did not show any significant difference $(P>0.05)$, meanwhile ketoconazole which was used as the positive control showed $100 \%$ inhibition on the growth of the fungus. The ethanolic extract of leave (ELE) had the highest inhibitory effect on $L$. theobromae by $100 \%$, followed by leave aqueous extract (ALE) and aqueous extract of the stem (ASE) with approximately $92.64 \%$ inhibition, respectively. The least inhibitory effect against $L$. theobromae was by aqueous extract of the seed (ASE) with $86.43 \pm 4.08 \%$ (Table 6). The inhibitory effect of ethanolic extract of the leave (ELE) against $L$. theobromae (100\%) was significantly $(P<0.05)$ greater than that of all the other extracts including ketoconazole. However, there was no significant difference $(P>0.05)$ between inhibitory effects of ethanolic seed extract, aqueous leave extract, ethanolic stem extract and aqueous stem extract. The control showed an effective inhibition of $75.19 \pm 1.77 \%$ but not significantly $(P<0.05)$ higher than all the other extracts (Table 6).

Ethanolic extract of the neem plant seed (ESE) gave the highest inhibitory effect on Sclerotium rolfsii $(87.99 \pm 2.42 \%)$, followed by ethanolic leave extract (ELE) $(85.66 \pm 2.92 \%)$, while aqueous extract of stem bark (ABE) showed the least inhibition (70.93 $\pm 5.81 \%)$. The inhibitory effect of ethanolic extract of the leave (ELE) was not significantly different $(P>0.05)$ from that of aqueous seed extract (ASE) and ethanolic leave extract (ELE). Also there was no significant difference $(P>0.05)$ between the inhibitory effect of aqueous leave extract, aqueous stem extract, ethanolic stem extract and aqueous seed extract.

Ketoconazole showed an effective inhibitory effect $(100 \%)$ on the growth of the fungus. The values obtained in this study are similar to what was reported by Anukworji et al. [25]. They treated S. rolfsii and L. theobromae isolated from cocoyam with aqueous and ethanolic extract of neem leaf.

These results agreed with the finding of many researchers. Amadioha [26] discovered that aqueous neem seed and neem extract reduced the growth of the fungi particularly Pyricularia oryzae on rice. Bennett and Wallsgrove [27]; Grayer and Harbourne [28], observed that neem phytochemicals (glycosides and saponins) have antifungal activity. Osbourn [29], observed that many saponins exhibit potent antifungal activity and are often present in relatively high levels in healthy plants and as a

Table 5 Percentage mean zones of inhibition of plant extracts on fungal rot of cocoyam

\begin{tabular}{lccc}
\hline Extract & A. niger (\%) & A. oryzae (\%) & R. stolonifer (\%) \\
\hline Ethanolic seed extract (ESE) & $88.37 \pm 1.17^{\mathrm{a}}$ & $91.47 \pm 2.93^{\mathrm{a}}$ & $84.88 \pm 3.07^{\mathrm{a}}$ \\
Aqueous seed extract (ASE) & $81.78 \pm 2.92^{\mathrm{ab}}$ & $85.66 \pm 2.92^{\mathrm{ac}}$ & $79.07 \pm 2.33^{\mathrm{ab}}$ \\
Ethanolic leave extract (ELE) & $77.52 \pm 1.35^{\mathrm{b}}$ & $90.70 \pm 2.33^{\mathrm{ac}}$ & $76.74 \pm 2.33^{\mathrm{ab}}$ \\
Aqueous leave extract (ALE) & $72.87 \pm 3.55^{\mathrm{b}}$ & $85.66 \pm 2.92^{\mathrm{ac}}$ & $75.97 \pm 3.55^{\mathrm{b}}$ \\
Ethanolic stem bark extract (EBE) & $39.53 \pm 8.39^{\mathrm{c}}$ & $84.51 \pm 1.76^{\mathrm{c}}$ & $91.47 \pm 5.85^{\mathrm{cd}}$ \\
Aqueous stem bark extract (ABE) & $87.21 \pm 1.16^{\mathrm{ab}}$ & $96.79 \pm 1.60^{\mathrm{d}}$ & $94.96 \pm 1.34^{\mathrm{d}}$ \\
Ketoconazole & $89.92 \pm 1.35^{\mathrm{a}}$ & $100.00 \pm 0.00^{\mathrm{d}}$ & $88.76 \pm 0.68^{\mathrm{c}}$ \\
\hline
\end{tabular}

Values are mean \pm standard deviation $(n=3)$

Means in the same column with the same superscript letter are not significantly different at $P<0.05$ 
Table 6 Percentage mean zones of inhibition of plant extracts on fungal rot of yam

\begin{tabular}{lccr}
\hline Extract & A. ochareus (\%) & L. theobromae (\%) & S. rolfsii (\%) \\
\hline Ethanolic seed extract (ESE) & $87.21 \pm 1.16^{\mathrm{a}}$ & $89.53 \pm 1.17^{\mathrm{ab}}$ & $87.99 \pm 2.42^{\mathrm{a}}$ \\
Aqueous seed extract (ASE) & $82.27 \pm 0.50^{\mathrm{b}}$ & $86.43 \pm 4.08^{\mathrm{a}}$ & $79.46 \pm 2.93^{\mathrm{ab}}$ \\
Ethanolic leave extract (ELE) & $88.37 \pm 2.33^{\mathrm{a}}$ & $100.00 \pm 0.00^{\mathrm{c}}$ & $85.66 \pm 2.92^{\mathrm{a}}$ \\
Aqueous leave extract (ALE) & $81.78 \pm 3.74^{\mathrm{b}}$ & $92.64 \pm 1.78^{\mathrm{b}}$ & $74.80 \pm 2.42^{\mathrm{b}}$ \\
Ethanolic stem bark extract (EBE) & $87.60 \pm 1.34^{\mathrm{a}}$ & $86.82 \pm 1.78^{\mathrm{ab}}$ & $77.91 \pm 4.19^{\mathrm{b}}$ \\
Aqueous stem bark extract (ABE) & $93.80 \pm 1.78^{\mathrm{c}}$ & $92.64 \pm 2.42^{\mathrm{b}}$ & $70.93 \pm 5.81^{\mathrm{b}}$ \\
Ketoconazole & $100.00 \pm 0.00^{\mathrm{d}}$ & $75.19 \pm 1.77^{\mathrm{d}}$ & $100.00 \pm 0.00^{\mathrm{c}}$ \\
\hline
\end{tabular}

Values are mean \pm standard deviation $(n=3)$

Means in the same column with the same superscript letter are not significantly different at $P<0.05$

result have been implicated as determinants of a plant's resistance to fungal attack.

This suggests that these phytochemical components might have been responsible for the observed antifungal properties of the test plant used in the present study.

On the contrary, Oluma and Elaigwe [30] observed that extracts of $A$. indica had no inhibitory effect on the mycelial growth and sclerotial formation of Macrophomina phaseolina. Premlatha [31] also gave similar report on the ineffectiveness of neem extract against Rhizoctonia solani. But Nwachukwu and Umechuruba [32] stated that leaf extracts of neem were shown to be efficacious on major seed-borne diseases of African cocoyam bean seeds and on seed germination and seedling emergent diseases. The active principles present in plants are influenced by many factors, which include the age of plant, extracting solvent, method of extraction and time of harvesting plant materials [33]. According to Okigbo and Ogbonnaya [33], the use of plants extracts for plant disease management is economically viable and poses little environmental risk, and the plants are available to farmers in Nigeria, the tropics and many parts of the world that do not have ready access to other synthetic fungicides. Umar et al. [34] and Makein et al. [35] pointed out that Azadirachtin extracts from the seeds, leaves and bark of the neem tree has been reported to have strong biological activities against insect pest, but with very low toxicity to mammals and the environment. According to Kurucheve et al. [36], the presence of inhibitors to the fungal toxic principle may contribute to differences observed in the antifungal activity of some plant extracts.

\section{Conclusion}

All the plant extracts showed antifungal activities at varied percentage mean zones of inhibition. Various neem plant parts extracts showed inhibition against fungal growth from isolates of rotted cocoyam with mean inhibition between $39.53 \pm 8.39 \%$ and $96.76 \pm 1.60 \%$. Apart from ethanolic stem bark extract which gave $39.53 \pm 8.39 \%$ limited zone of inhibition against $A$. niger growth, the rest of the extract exhibited good zones of inhibition ranging between $72.87 \pm 3.55$ and $96.79 \pm 1.60 \%$. The extracts were effective against fungal isolates from the rotten yam samples. The mean percentage zones of inhibition of all extracts of the neem plant parts showed more effectiveness than the positive control (Ketoconazole) against $L$. theobromae growth. Aqueous stem bark extract with $93.80 \pm 1.78 \%$ mean zone of inhibition showed comparable effectiveness to the control (100\% inhibition) against $A$. ochareus growth, while against $S$. rolfii growth there was good inhibition by all the extracts though not as that of the control. The fungi toxic potential of these plant extracts on rot-inducing fungi of stored yam and cocoyam recommends their use to farmers as alternative to commercial/synthetic fungicides.

\section{Abbreviations}

ABE: aqueous stem bark extract; ASE: aqueous seed extract; EBE: ethanolic stem bark extract; ELE: ethanolic leave extract; ESE: ethanolic seed extract.

\section{Authors' contributions}

CSE, Al and AJ carried out the field/laboratory operations. CSE designed the study. Data analysis were by CSE, Al, AJ and Cl. Supporting literature was by DIA. Preparation of manuscript was carried out by CSE, DIA and CI. All authors read and approved the final manuscript.

\section{Author details}

${ }^{1}$ Department of Biochemistry, Federal University Wukari, Wukari, Taraba State, Nigeria. ${ }^{2}$ Department of Microbiology, Federal University Wukari, Wukari,

Taraba State, Nigeria.

\section{Acknowledgements}

The authors acknowledge the immense contributions of Laboratory Technologists of Biology, Biochemistry and Microbiology Departments of the Federal

University Wukari, Taraba State, Nigeria.

\section{Competing interests}

The authors declare that they have no competing interests. 


\section{Availability of data and materials}

Additional data may be available on request to the authors; please contact corresponding author

\section{Consent for publication}

This work was the mutual efforts of the authors with no external commitments. All the authors have given their consent through the corresponding author for publication of this work.

\section{Ethics approval and consent to participate}

Not applicable.

\section{Funding}

This work was not funded by any research grant, it was the efforts of the authors

\section{Publisher's Note}

Springer Nature remains neutral with regard to jurisdictional claims in published maps and institutional affiliations.

Received: 15 June 2018 Accepted: 7 August 2018

Published online: 11 September 2018

\section{References}

1. Mahmoud DA, Hassanein NM, Youssef KA, Abou Zeid MA. Antifungal activity of different neem leaf extracts and the nimonol against some important human pathogens. Braz J Microbiol. 2011;42:1007-16.

2. Arumugam PA, Mohamad I, Salim R, Mohamed Z. Antifungal effect of Malaysian neem leaf extract on selected fungal species causing Otomycosis in in-vitro culture medium. Malays J Med Health Sci. 2015;11(2):69-84.

3. IITA. Production cost in the yam based cropping system of South-eastern Nigeria, RCMP Monograph Ibadan, Nigeria. 1991;6:2-26.

4. IITA. Production of yams, present and future perspective. IITA Res Guide. 1993;46:5.

5. Musa YH, Onu JI, Vosanka IP, Anonguku I. Production efficiency of yam in Zing Local Government Area of Taraba State, Nigeria. J Hortic For. 2011;3(12):372-8.

6. Opara LU. YAMS: post-harvest operation. AGST/FAO. In: Danilo Mejía Ed. FAO Technical. INPhO Post harvest compendium. New Zealand; 2003.

7. Igbozulike AO. Evaluation of cocoyam corms processing and storage in Nigeria. Int J Sci Eng Res. 2015:6(7):259-63.

8. Ijioma JC, Effiong JB, Ogbonna MO, Onwuamaoka EA. Determinants of adoption of selected NRCRI cocoyam technologies among farmers in Umuahia South Local Government Area of Abia State, Nigeria. Am Int J Contemp Res. 2014;4:6.

9. National Root Crops Research Institute (NRCRI) Umudike, Cocoyam Program. http://www.nrcri.org. Accessed 13 Feb 2015.

10. Chukwu GOC, Nwosu KI, Madu TU, Chinaka C, Okoye BC. Development of gocing storage method for cocoyam. Munich Personnel RePEc Archives (MPRA) Paper No 17444:25; 2008.

11. Opata PI, Ogbonna PE. Storage profitability and effectiveness of storage methods in yield loss reduction in cocoyam in southeast Nigeria. Afr J Agric Res. 2015;10(49):4496-504. https://doi.org/10.5897/AJAR2015.9756.

12. FAOSTAT. Food and Agricultural Organization: Agricultural Statistics. Rome: FAO; 2010

13. Green KR. Studies on the epidemiology and control of yam anthracnose. Ph.D. Thesis, University of Reading, Reading, UK. 1994.

14. Cheesbrough M. District laboratory practice in tropical countries. Part 2. London: Cambridge University Press; 1984. p. 134-242.

15. Oniyike RCI, Maduewesi JNC. Variability in pathogenicity of isolates and sensitivity of dithane M-45 and PCNB on cocoyam rot Fungi. Niger J Plant Protect. 1985;9:74-81.

16. Okigbo RN, Ikediugwu FEO. Studies on biological control of postharvest rot of yam (Dioscorea sp.) with Trichoderma viride. J Phytopathol. 2000;148:351-5

17. Alexopoulos CJ. Introductory mycology. 2nd ed. Sydney: Wiley; 1962. p. 119-59.
18. Nelson PE, Tousson TA, Marasssas WFO. Fusarium species, an illustrated manual for identification. University Park: The Pennsylvania state press; 1983. p. 193.

19. Rippon JN. Medical mycology: the pathogenic fungi and the pathogenic actinomycetes. 3rd ed. Philadelphia: W.B. Saunders Co.; 1988. p. 163.

20. Samson RA, Hockstra ES, Van-Orschot AN. Introductory to food borne fungi. Amsterdam: The Netherlands academy of arts and science; 1984. p. $1-25$

21. Snowdon AL. A Colour atlas of postharvest diseases and disorders of fruits and vegetables UK, vol. 2. London: Wolfe scientific books; 1991. p. 416.

22. Okafor N. Microbial rotting of stored yam (Dioscorea spp) in Nigeria. Exp Agric. 1966;2:179-82.

23. Sangoyomi TE, Ekpo EJA, Asiedu R. Fungitoxic effects and attributes of Allium sativum and Occimum gratissimum extracts on Rhizoctonia solani, the causal organism of yam Dioscorea rotundata (Poir) rot disease. Niger J Mycol. 2009;2(1):166-7

24. Whipps JM. Effects of media on growth and interactions between a range of soil borne glass pathogens and antagonistic fungi. New Pathol. 1987; 107:127-42

25. Anukworji CA, Ramesh RP, Okigbo RN. Isolation of fungi causing rot of cocoyam (Colocasia esculenta (L.) Schott) and control with plant extracts: (Allium sativum, L., Garcinia kola, heckel., Azadirachta indica, L. and Carica papaya, L.). Glob Adv Res J Agric Sci. 2012;1(1):202-17.

26. Amadioha AC. Controlling rice blast in vitro and in vivo with extracts of Azadirachta indica. Crop Prot. 1999;19:287-90.

27. Bennett RN, Wallsgrove RM. Secondary metabolites in plant defence mechanisms. New Phytol. 1994;127:617-33.

28. Grayer RJ, Harbourn JJ. A survey of antifungal compounds from higher plants. Phytochemistry. 1994;37:19-42.

29. Osbourn AC. Saponins and plant defence-a soap story. Trends Plant Sci. 1996;1:4-9.

30. Oluma HOA, Elaigwe M. Antifungal activity of extracts of some medicinal plants against Macrophomina phaseolina. J Bot. 2006;19(1):121-8.

31. Premlatha D. Effect of some soil amendment with some green manure on the survival of sclerotia of Corticum Sesaki. Indian Phytopathol. 1982;35:523-5.

32. Nwachukwu EO, Umechuruba $\mathrm{Cl}$. Antifungal activities of some leave extracts on seed-borne fungi of African yam bean seeds. J Appl Nat Sci. 2001;1:29-31

33. Okigbo RN, Ogbonnaya UO. Antifgunal effects of two tropical plant extracts (Ociumu gratissiumum and Afromomum melequeta) on postharvest yam (Dioscorea spp.) rot. Afr J Biotechnol. 2006;5:5727-31.

34. Umar A, Abdulraham HT, Kokori M. Preliminary studies of the efficiencies of the aqueous extracts of leaf and seed kernel of neem for the control of cowpea bruchid Callobruchus maculates. Res J Sci. 2002;8(1 and 2):25-30.

35. Makein HK, Maikai VA, Nok JA. Effect of topical application of neem seed extract on sheep infested with Amblyomma variegatum. Afr J Biotechnol. 2007:6(20):2324-7.

36. Kurucheve V, Padmavathi R. Fungitoxicity of selected plant products against Pythium aphanidermatum. Indian phytopathol. 1997:50:529-35.

\section{Submit your manuscript to a SpringerOpen ${ }^{\circ}$ journal and benefit from:}

- Convenient online submission

$\checkmark$ Rigorous peer review

- Open access: articles freely available online

- High visibility within the field

Retaining the copyright to your article

Submit your next manuscript at $\gg$ springeropen.com 